\title{
The Path to Innovation: An Amalgamation of Patent Law and the Dynamic Competition Regime
}

Ketana Krishna* and Sushma Sosha Philip**

\section{Abstract}

The purpose of this paper is to identify a method to create a balance between competition laws and the patent protection regime so as to promote innovation. The relationship between competition law and the law relating to intellectual property has long been recognized to be a turbulent one. The traditional perspective adopted towards the relationship between the subjects is that one is opposed to the other; where intellectual property laws encourage and protect monopoly, competition laws seek to curb and control it. This research focuses on the possibility of change from the conventional view relating to competition law and intellectual property law by making the approach to these two subjects more innovation centric. The paper examines these apparently paradoxical disciplines from the perspective of innovation and finds that both intellectual property laws and competition laws have a common objective, which is to increase innovation. This paper undertakes conceptual

\footnotetext{
* Fourth Year, BA LLB (Hons.), National University of Advanced Legal Studies (NUALS), Kochi; ketana.krishna@nuals.ac.in

** Fourth Year, BA LLB (Hons.), National University of Advanced Legal Studies (NUALS), Kochi; sushpil@gmail.com
} 
research in order to develop new concepts and to reinterpret the existing ones. It analyses various economic theories of development and the existing conceptual framework pertaining to competition and patent laws. Finally, the paper suggests amendments in the existing law and proposes a new legal and policy framework that reconciles both the fields so as to promote effective innovation crucial for economic development and trade in India.

Keywords: Competition, Economic Theory, Innovation, Intellectual Property, Patents.

\section{The Patent-Competition Paradox}

There is a close link between patent rights and competition laws. While patent laws may contribute to fair market behaviour by ensuring prevention of copying or imitation of patented goods, competition laws limit patent rights, in that patent holders are barred from abusing their rights. ${ }^{1}$ The patent system is based on the concept of exclusion, while competition laws are contemptuous of exclusivity. Hence, the patent-competition paradox attains relevance.

Nevertheless, the relationship between intellectual property rights and competition law is not pure but contradictory. Both competition and patent policies, if properly balanced, foster innovation. Competition law does so by protecting competition, and patent law, by promoting dynamic innovation along multiple

1 World Intellectual Property Organization, Competition and Patents, WORLD INTELLECTUAL PROPERTY ORGANISATION, available at http://www.wipo.int/patent-law/en/developments/competition.html. (last visited on Apr. 23, 2015). 
Ketana Krishna et al.

dimensions. ${ }^{2}$ Failure to strike such a balance, however, can adversely affect innovation. ${ }^{3}$

\section{The Role of Intellectual Property in Innovation}

The general perception regarding patent law is that it enhances and encourages innovation by acting as an incentivizing mechanism, and thereby promotes economic growth. It has been statistically proven that patents produce a higher and more certain investment return on innovation, thus validating investments in research and development. 4 The theory that patents motivate useful inventions is one of the more perceptible benefits of the concept of granting patents. This theory is based on the presumption that the absence of a patent system would mean that there would be no incentives for innovation. Patent protection results in competitive research and development ( $R \& D)$, where firms invest their resources in research facilities with the by-product being innovation.

But there is another, much grimmer side to granting patent monopoly over innovations. Too many firms could invest their resources in $R \& D$ leading to an inordinate number of entities stampeding towards the same goal.

Larger firms holding patents tend to discourage smaller firms from venturing into the protected field for fear of adverse litigation. This in turn, will result in the reduction of innovative and inventive

2 Professor Greg Dolin, Resolving the Patent-Antitrust Paradox: Promoting Consumer Welfare Through Innovation, CENTRE FOR PROTECTION OF INTEllectual PROPERTY-GeORGE MASON UNIVERSITY SCHOOL OF LAW (May, 2013), http://cpip.gmu.edu/wp-content/uploads/2013/08/DolinPatent-Antitrust-Paradox.pdf.

3 Susan S. DeSantet. al., To Promote Innovation: The Proper Balance of Competition and Patent Law and Policy, FEDERAL TrAde COMMISSION (Oct., 2003),

http:/ / www.ftc.gov/sites/default/files/documents/reports/promoteinnovation-proper-balance-competition-and-patent-law-andpolicy/innovationrpt.pdf.

4 Bruce Nolan, The Experts: Does the Patent System Encourage Innovation, WSJ, (May 16, 2013), http://online.wsj.com/news/articles/ SB10001424127887323582904578487200821421958. 
efforts, which could have yielded in the production of supplementary products as well as enhanced the protected product.

Sometimes patent holders may obtain protection and monopoly for their inventions and then, either not put such innovation to any use, or not harness the full potential of such innovation. Due to the protection afforded by patents, no other entity can make use of such innovation till the patent on it expires. By such time, the effectiveness or utility of the innovation would have become obsolete.

In certain industries, patents play a negligible role as a means of protection of invention, or even, to take an extreme point of view, be considered to hamper innovation. This is observed especially in cases of emerging technological areas where the patents protect foundational inventions on which others as based, thus cordoning off vast areas of information and knowledge, which otherwise could have been harnessed for further research and development. ${ }^{5}$

Thus, granting absolute monopoly over an invention may not always be the best course for innovation from the point of view of the public.

\section{Intellectual Property Rights (IPR) in the Competition Act, 2002}

Section 3 of the Competition Act, 2002 prevents any business activity that is likely to cause an 'appreciable adverse effect' on competition in India. Section 3(5) has bestowed an exemption on intellectual property (IP). This exemption, however, does not go completely unchecked as Section 4 of the Act deals with the abuse of dominant position, and provides ample room for interfering with intellectual property matters as well. ${ }^{6}$ There are only a few

${ }^{5}$ Organisation for Economic Co-operation and Development, Patents and Innovation: Trends and Policy Challenges, OECD, available at http:/ / www.oecd.org/science/sci-tech/24508541.pdf (last visited on Apr. $28,2015)$.

6 K. D. Raju, The Inevitable Connection between Intellectual Property and Competition Law: Emerging Jurisprudence and Lessons for India, 18 J. INTELL. PROP. L. 111, 114 (2013). 
Ketana Krishna et al.

provisions that deal with intellectual property in the whole of the Competition Act, 2002. Considering the massive impact these fields have on each other, more comprehensive legislations regarding the IPR - competition law interface are essential.

\section{The Concept of Dynamic Competition}

Static competition manifests itself in the form of existing products offered at low prices. According to this model, no new products are introduced, and rapid price reductions driven by innovation do not exist. ${ }^{7}$ While this static framework has a theoretical simplicity and elegance, it tends to overlook industrial dynamics. 8 For these reasons, it is not a recognizable state of world. The concept of 'dynamic competition' has been variously defined. Some theorists argue that the dynamic competition models entail the prediction of future competitive outcomes, while others have observed that 'dynamic is shorthand for a variety of rigorously competitive activities such as significant product differentiation and rapid response to change, whether from innovation or simply new market opportunities ensuing from changes in 'taste' or other forces of disequilibrium.' Dynamic analysts tend to 'view competition through a broader lens and focus less on outcomes and more on processes. ${ }^{9}$ Dynamic competition is, in fact, more intuitive and much closer to the conventional view of competition, than the stylized notion of static competition routinely depicted in textbooks. ${ }^{10}$

When a concept of dynamic competition is developed, the economic rationale of intellectual property rights must be taken into account, and any conduct that is the result of intellectual

7 David J. Teece, Favouring Dynamic over Static Competition: Implications for Antitrust Analysis and Policy, InNOVATION FORUM-GMU (May 15, 2008), http:/ /innovationforum.gmu.edu/2008/papers/dynamic_static.pdf.

${ }^{8}$ Gregory Sidak and David J. Teece, Dynamic Competition in Antitrust Law, 5(4) JCLE 581, 631 (2009).

9 J GRegory SidAK AND DAVID TEECE, INTEllectual Property, COMPETITION LAW AND ECONOMICS IN ASIA 70 ( R. Ian McEwin, 2011).

10 Sidak \& Teece, supra note 8. 
property law must be recognised as pro-competitive to the extent that it lies within the common economic rationale of IP and competition law. ${ }^{11}$ Unfortunately, this intersection between the two branches of law remains a grey area.

In today's technology driven world, innovation is crucial to success. Innovation leads to new products and production technologies. It allows new firms to enter into markets dominated by incumbents, and is critical for incumbent firms who want to continue their previous market successes and stimulate consumer demand. Competition drives innovation. Without competition, there would be little pressure to introduce new products or new production methods and the economy would lag behind, thus losing international competitiveness. ${ }^{12}$ Using static analysis to address antitrust issues in a dynamic economy is unlikely to improve consumer welfare. A more dynamic analytical framework increases the likelihood of helping rather than hurting consumers. ${ }^{13}$

Various theorists support the proposition that dynamic competition is the way towards increasing innovation. Joseph Schumpeter ${ }^{14}$ was a strong advocate of the dynamic theory of competition. Schumpeter's main objective was to set up a dynamic framework to stand alongside and complement the static one. ${ }^{15}$ Schumpeterian

11 Olav Kolststad, COMPETition LaW And Intellectual Property RIGHTS - OUTLINE OF ECONOMICS - BASED APPROACH, RESEARCH HANDBOOK ON INTELLECTUAL PROPERTY AND COMPETITION LAW 10 (Josef Drexl, Edward Elgar Publishing Limited, 2008).

12 William J. Kolasky, The Role of Competition in Promoting Dynamic Markets and Economic Growth, U.S. DEPARTMENT OF JUSTICE (Nov. 12, 2002), http://www.justice.gov/atr/public/speeches/200484.htm.

${ }^{13}$ SIDAK \& TEECE Supra note 8, p. 585.

14 Joseph Alois Schumpeter, an Austrian-American, was one of the most influential economists and political scientists of the $20^{\text {th }}$ Century. He analysed and popularised the term "creative destruction" and propounded a theory which revolutionized the approach to economics and innovation- the Schumpeterian theory of economics.

15 JOHN A. MATHEWS, REFLECTIONS ON SCHUMPETER'S LOST SEVENTH CHAPTER TO THE THEORY OF ECONOMIC DEVELOPMENT, ELGAR COMPANION 
Ketana Krishna et al.

competition is engendered by product and process innovation. Such competition does more than bringing price competition; it tends to overturn the existing order. A framework for antitrust analysis that favours dynamic competition over static competition would place less weight on market share and concentration in the assessment of market power and more weight on assessing innovation and enterprise level capabilities. ${ }^{16}$

Further evidence that innovation is a natural result of competition was given by Schmookler, ${ }^{17}$ who demonstrated that the appearance of clusters of patents in various industries after major productive investment in those industries showed that invention and innovation were generally demand led and not technology led. ${ }^{18}$

While Schumpeterian competition drives innovation, it also begets imitators and swarms of those who copy their rival's innovation, attracting investment and leading to a boom. When the original innovator's profit advantage is eliminated, investment moves elsewhere and the sector may even shrink, until the next disruptive innovation restarts the cycle. ${ }^{19}$

Neo-Schumpeterian economics modifies the Schumpeterian theory slightly seeking to get a grip on the dynamic phenomena of

TO NEO-SCHUMPETERIAN ECONOMICS 81 (Horst Hanusch and Andreas Pyka, Edward Elgar Publishing Limited, 2007).

16 Sidak, Gregory and Teece, David, Rewriting the Horizontal Merger Guidelines in the Name of Dynamic Competition, 16 Geo. Mason L. Rev. 885,885 (2009).

17 Jacob Schmookler was an American economist who is best known as the first economist to successfully explore statistically, the economics of technological innovation at the industrial level, in great detail.

18 CHRIS FREEMAN, A SCHUMPETERIAN RENAISSANCE?: ELGAR COMPANION TO NEO-SCHUMPETERIAN ECONOMICS 134 (Horst Hanusch and Andreas Pyka, Edward Elgar Publishing Limited, 2007).

19 Thomas C. Leonard, Prophet of Innovation: Joseph Schumpeter and Creative Destruction, PRINCETON. EDU (Apr. 28, 2015), https://www.princeton.edu/ tleonard/papers/McCraw.pdf. 
economic reality. ${ }^{20}$ In the Neo-Schumpeterian approach, innovation competition takes the place of price competition as the coordination mechanism of interest, thus propelling economic dynamics. ${ }^{21}$ While prices only concern the adjustment to limiting conditions, innovations overcome such limitations and establish a new order.

Another influential 20 th century economist, Kenneth Arrow,22 reemphasized the fact that competition, rather than monopoly, promotes innovation. ${ }^{23}$ He observed that monopolists bear a cost while innovating, which a competitor may not incur. Monopolists give up the opportunity in order to continue earning monopoly profits without innovating. In consequence, the incremental gains enjoyed from innovation by the monopolist may be less than those of a firm in a competitive setting that would expect to earn similar post-innovation profits. ${ }^{24}$

Thus, all these theories result in the same inference, i.e. competition promotes innovation, which is the hallmark of development.

\section{Dynamic Competition in the Indian Economy}

Post-independence, Indian socialism systematically restricted and eliminated competition in many sectors of the Indian economy. ${ }^{25}$ However, in the early 1980's, there was a shift towards liberalisation and economic reform. India adopted economic

20 HORST HANUSH AND ANDREAS PYKA, INTRODUCTIONS, ELGAR COMPANION TO NEO-SCHUMPETERIAN ECONOMICS 1 (Horst Hanusch and Andreas Pyka, Edward Elgar Publishing Limited, 2007).

${ }^{21} \mathrm{Id}$.

22 (A Nobel Prize-winning economist who has taught at Stanford and Harvard.)

23 Jonathan B. Baker, Beyond Schumpeter vs. Arrow: How Antitrust Fosters Innovation, 74 ANTITRUST L.J. 575, 578 (2007).

${ }^{24} \mathrm{Id}$.

25 Arvind Virmani, The Dynamics of Competition: Phasing of Domestic and External Liberalisation in India, PLANNING COMMISSION (Apr., 2006), http://planningcommission.nic.in/reports/wrkpapers/wp_dc_pdel.pdf. 
Ketana Krishna et al.

reforms in order to create a competitive environment for stimulating growth and competitiveness. ${ }^{26}$

In the financial year 2015, the Indian GDP is poised to increase to $7.4 \%$ (advanced estimates). ${ }^{27}$ The Indian market is in a constant state of evolution due to globalization and liberalization and a stagnant competition policy cannot cater to such an economy. Recent literature emphasizes the importance of dynamic efficiency as a legitimate objective of competition policy. This is often associated with the benefits arising from technological change, learning and economic growth accumulated over time. ${ }^{28}$ It has thus been made amply clear that competition law enforcers should emphasize their focus on protecting the dynamic 'process of competition' and not on the 'outcome' in terms of uncertain future consumer preferences. ${ }^{29}$

The Constitution of India ${ }^{30}$ mandates, inter alia, that the State shall direct its policy towards ensuring that the ownership and control of material resources of the community are so distributed as best to subserve the common good; and that the operation of the economic system does not result in the concentration of wealth and means of production to the common detriment. ${ }^{31}$

26 Vikram Chadha and Navdeep Kumar, Impact of India's New Competition Policy on the Competitiveness of the Indian Industry, 2 WORLD REVIEW OF BUSINESS RESEARCH 120, 121 (2012).

27 Ministry of Finance, PRESS INFORMATION BUREAU, GOVERNMENT OF INDIA, Budget 2015-16, (Feb. 27, 2015), http:/ / pib.nic.in/budget2015/ecosurveyRel.aspx.

28 Rafaelita M. Aldaba, Emerging Issues in Promoting Competition Policy under Regional Frameworks, 2 PIDS DISCUSSION PAPER SERIES (2008), (Jan. ,2008), http://dirp4.pids.gov.ph/ris/dps/pidsdps0802.pdf.

29 FICCI IPR Division, Indo-German Conference on Intellectual Property Rights, FICCI, (Mar. 10-11, 2011), http://www.kas.de/wf/ doc/ kas_30136-1522-1-30.pdf?120208121353.

30 THE CONSTITUTION OF INDIA, Art. 38 and Art.39.

31 Dr. S. Chakravarthy, Why India Adopted a New Competition Law, CUTS INTERNATIONAL, (Aug. 2006), http://www.cuts-international.org/ pdf/wiancl.pdf. 
Furthermore, the Competition Act, 2002 anticipates implementation of competition law in a dynamic framework of innovation and growth as it dwells on the benefits of competition law, as a stamp of approval on achieving market oriented economic development. ${ }^{32}$ There is a need to ensure that competition authorities get it right and that the dynamism of the market is also not sapped of its competitive vigour on account of over enthusiasm.

\section{Interdependent Nature of Competition and Patents: Perceived Differences between the Two Fields}

The intersection between intellectual property law and competition law has been studied in great detail, with some observers focusing on the presupposed 'tension' between these two bodies of law. Carl Shapiro $^{33}$ in his works on the subject has stated that there is no need for any such tension if antitrust law properly recognizes the importance of providing incentives, along with the necessary flexibility, for industry participants to conduct research, engage in product development and diffuse the resulting innovations widely in the marketplace. An example to the contrary would be the fact that in spite of Section 3(5) (i) of the Competition Act, 2002,34

32 Dr.GeetaGouri, Making Markets Work Effectively in India Experience of the Competition Commission, JAPAN FAIR TRADE COMMISSION, (Apr. 30, 2015), http://www.jftc.go.jp/cprc/koukai/sympo/2012notice.files/130222sym po3.pdf.

33 Carl Shapiro is the Transamerica Professor of Business Strategy in the Haas School of Business at the University of California at Berkeley. Shapiro had the honor of serving as a Member of the President's Council of Economic Advisers during 2011-12. He has been Editor and Co-Editor of the Journal of Economic Perspectives and a Fellow at the Center for Advanced Study in the Behavioral Sciences, among other honors. Shapiro earned his PhD in Economics at M.I.T. in 1981, taught at Princeton University during the 1980s.

34 The right of any person to restrain any infringement of, or to impose reasonable conditions, as may be necessary for protecting any of his rights which have been or may be conferred upon him under-

(a) the Copyright Act, 1957 (14 of 1957); 
Ketana Krishna et al.

authorities have prohibited certain activities of intellectual property owners which, though lawful under IPR legislations, contravene some of the competition law provisions. ${ }^{35}$

IP laws recognizing a certain degree of competition could also greatly contribute in diffusing this perceived tension. Intellectual property rights give innovators the financial incentive to undertake the risks of dynamic competition. Additionally, licensing freedom permits innovators to find the royalties that will reward them and the most efficient co-producers, that can bring products to consumers; and the recognition that IP rights do not presumptively create market power, helps to ensure that successful innovators will not be bogged down by rivals who misuse the competition laws to force compulsory licenses or other erosions of IP rights.

\section{Inherent Similarity of Goals}

Dynamic efficiency is the hallmark of growth oriented economies. ${ }^{36}$ Embracing dynamic competition eases the tension between intellectual property and antitrust concerns. The patent system provides some amount of exclusion and such exclusion is required to foster innovation, particularly in more competitive market

(b) the Patents Act, 1970 (39 of 1970);

(c) the Trade and Merchandise Marks Act, 1958 (43 of 1958) or the Trade Marks Act, 1999 (47 of 1999);

(d) the Geographical Indications of Goods (Registration and Protection) Act, 1999 (48 of 1999);

(e) the Designs Act, 2000 (16 of 2000);

(f) the Semi-conductor Integrated Circuits Layout-Design Act, 2000 (37 of 2000).

35 RAJU, Supra note 6.

${ }^{36}$ Gerald F. Masoudi, Intellectual Property and Competition: Four Principles For Encouraging Innovation, DIGITAL AMERICAS 2006 MEETING, INTELLECTUAL PROPERTY AND INNOVATION IN THE DigITAL WORLD, DEPARTMENT OF JUSTICE, (Apr. 11, 2006), http://www.justice.gov/atr/public/speeches/215645.html. 
environments. ${ }^{37}$ IPR and competition law both promote dynamic efficiency, i.e., a system of property rights and market rules that create appropriate incentives for invention, innovation and the risks involved in R\&D. ${ }^{38}$ Whether competition law intervenes and restrains IPR is still a matter of deliberation.

With coordination between patent offices and the competition authority, mitigating the adverse effect of strong intellectual property rights regimes would become a possibility. ${ }^{39}$

The primary aim of intellectual property rights is to protect and incentivise innovation as well as to grant monopoly rights over the invention in question for a limited period of time and the aim of the competition policies of various countries are generally to ensure fair competition in the market by way of regulatory mechanisms. They are not intended to create restrictions or constraints that may be detrimental to the growth of the society. Intellectual property laws per se are not abusive of competition, however, they may be applied to this effect. For example, companies, by refraining from licensing their intellectual property to competitors, may undermine the basic tenets of competition law as well as the spirit of intellectual protection. $^{40}$

Competition law has traditionally focussed on static competition and the allocation of resources, accounting for the effects of dynamic competition and dynamic efficiency. Even if competition and IP legislations share a common goal, the supremacy of static efficiency in practice has created a conflict. ${ }^{41}$ Thus, a shift in focus to a more dynamic view on competition is essential.

37 SIDAK \& TEECE, Supra note 8.

38 RAJU, supra note 6.

39 Pradeep S. Mehta \& Ujjwal Kumar, Competition Policy and the Poor, CUTS CENTRE FOR INTERNATIONAL TRADE, ECONOMICS \& ENVIRONMENT,( Apr. 2, 2015), http:/ / www.cuts-international.org/viewpoint.html.

40 RAJU, supra note 6.

41 Josef Drexl, Research Handbook on Intellectual Property and COMPETITION LAW (Edward Elgar Publishing, 2008). 
Ketana Krishna et al.

IP protection provides incentives for innovation and technological diffusion, which in themselves are important sources of competition in the marketplace and therefore support competition. Similarly, competition stimulates innovation, thereby contributing to the development of intellectual property. Competition law protects incentives to innovate from anti-competitive conduct that would create, enhance or maintain market power or otherwise cause vigorous rivalry among firms. ${ }^{42}$

In sum, the argument is that there is no conflict in the ends being sought by intellectual property rights and competition law though there may be some differences in the means through which these goals are sought to be achieved. In both cases, the promotion of innovation, consumer welfare and more product choices ${ }^{43}$ is the common aim.

\section{A Nationwide Approach to Innovation}

A nationwide approach to innovation is more beneficial than an industry wise approach, as a national framework for innovation is much more than just a network of institutions supporting research and development.

Given that there is a positive relationship between competition policy and productivity as also investment and export performance, an effective innovation approach fostering a flexible, dynamic and competitive industrial sector would lead a country to sustained development. An innovative market is one of the best ways to stimulate productivity. ${ }^{4}$ Studies conducted by the World Bank reveal that economies with greater competition have higher levels of economic growth and enhanced productivity.

What is required is a comprehensive Neo-Schumpeterian economic theory focussing on innovation driven qualitative development and

42 Rishika Sugandh \& Siddhartha Srivastava, Interface Between Intellectual Property Rights and Competition Law: Indian Jurisprudence, 1(2) IJLLJS (2014).

43 Abhishek Adlakha, Intellectual Property and Competition Law: The Innovation Nexus, 4 CIRC IssUE, (Sep. 2, 2014), http://circ.in/pdf/ Intellectual_Property_and_Competition_Law-The_Innovation_Nexus.pdf.

44 VIRMANI, supra note 25. 
offering theoretical concepts to analyze the various issues of three sectors: Industry, Finance and Public Sector. ${ }^{45}$

A Neo-Schumpeterian approach will give a complete picture of what is required for radical innovation resulting in growth. Such an attitude adopted towards the market and economy will place importance on making policies, keeping in view that while the vast majority of firms do not make radical innovations, everyone can make incremental innovations by adopting new products and processes made by others. ${ }^{46}$ There will be a shift in emphasis towards diffusion across India.

Thus, as it persuades innovation, while factoring in a wider range of aspects other than the traditional Schumpeterian theory, a NeoSchumpeterian approach is apposite for the volatile Indian market scenario.

\section{Towards a Legislation Best Suited for the Indian Market}

The essential feature of India's economic system can be identified as a dynamic transformation process of industrial networks, in which entrepreneurship and innovation play key roles. A solid competition regime and an independent system of enforcing provisions to aid innovation are essential to economic development and to the welfare of the society, in a developing country like India.

Developing economies have made great strides in the last century in promoting the rule of law and the basics of market economics, but these are not necessarily enough to fuel robust growth. These factors create the right conditions for static efficiency. However, only predictable and enforceable intellectual property rights will create the ideal conditions for dynamic efficiency to flourish. It is apparent that creating a dynamic private market with strong IP

45 Horst Hanusch \& Andreas Pyka, A Roadmap to Neo-Schumpeterian Economics, UNIVERSITY OF AUGSBURG, (Jul., 2005), http:/ / www.uq.edu.au/economics/PDF/int/Hanusch\&Pyka.pdf.

46 C.S. Sundaresan, Realism and Applied Economics- An Analysis of Growth Theories from Neo-Schumpeterian to Neo-Keynesian, ICOAE-2009, (May 27, 2009), http:/ / kastoria.teikoz.gr/icoae2/wordpress/wp-content/uploads/ articles/2011/10/062-2009.pdf. 
Ketana Krishna et al.

rights is the most efficient way to drive economic growth, as private and individual decisions tend to be quicker, more varied, and more directly responsive to consumer demands than government decisions are. ${ }^{47}$

An innovation policy will play a key role in fostering dynamic markets and in stimulating economic growth. International competitiveness of industries depends on access to inexpensive inputs, improvements in efficiency and productivity, all of which would find favour with the promotion of innovation. A well constructed statute on innovation, backed by an enforcement agency with strong powers and an economically sound enforcement policy is critical in order for the markets to deliver the economic growth that they promise. 48

By embedding recent developments in evolutionary economics, the behavioural theory of the firm and strategic management into antitrust analysis, one can develop a more robust framework to promote innovation. Such a framework will most likely be instrumental towards reducing the gap between the fields and also the dependence on the standard tools of antitrust economics; particularly when the business environment manifests rapid technological change, which is a major stumbling block for both IP and competition regimes. ${ }^{49}$

The Organisation for Economic Co-operation and Development (OECD) defines innovation as 'new products, business processes and organic changes that create wealth or social welfare.' Richard Lyons, the Chief Learning Officer at Goldman Sachs, offers a more condensed version as 'fresh thinking that creates value.' These definitions are the foundation on which deliberations have been based.

\footnotetext{
47 RAJU, supra note 6.

48 KOLSTSTAD, supra note 11.

49 SIDAK \& TEECE, supra note 8.
} 
To enable innovation in India, a recent World Bank report suggests a three pronged strategy: 50

Firstly, increasing competition as part of efforts to improve the investment climate, supported by stronger skills, better information infrastructure and more finance, both public and private.

Secondly, strengthening efforts to create and commercialize knowledge as well as adopting better methods to diffuse existing global and local knowledge and increasing the capacity of smaller enterprises to absorb it. If all enterprises could, without cost, achieve national practices based on knowledge already in use in India, economic output could more than quintuple.

Thirdly, fostering more inclusive innovation by promoting formal $R \& D$ efforts for the economically less privileged thereby facilitating the development of creative grassroots efforts and by improving the ability of informal enterprises to exploit pre-existing knowledge.

\section{A Critique of the National Innovation (Draft) Act 2008}

The Department of Science and Technology has introduced 'The National Innovation (Draft) Act' (the Act) in 2008. ${ }^{51}$ The proposed legislation aims at giving a push to innovation by exploiting technology and compensating for the lack of innovation oriented provisions in the current Patents Act, 2005.52

50 Mark A. Dutz, Unleashing India's Innovation- Toward Sustainable and Inclusive Growth, WORLD BANK, (Apr. 03, 2015), http:/ / siteresources.worldbank.org/SOUTHASIAEXT/Resources/22354 6-1181699473021/3876782-1191373775504/indiainnovationfull.pdf.

51 Patil, Gouramma, Critical Analysis of 'The National Innovation (Draft) Act, 2008, SSRN (Mar. 26, 2013), http:/ / dx.doi.org/10.2139/ssrn.2239718.

52 LexOrbis, India: A Probe On The Proposed National Innovation Act, 2008, MONDAQ,

(Oct.

14 , 2008), 
Ketana Krishna et al.

The term 'innovation' has been defined in the proposed Act to include only those processes that are directed towards achieving technical/ technological advances and such innovations as are different from any new or innovative technology that was achieved as a by-product of such innovation. Further, any product or process arising out of innovation, protected by any already existing legislation on IPR, will not fall under the ambit of the present statute. Thus, such product or process, though falling under the theoretical definition of innovation, will not avail any of the benefits from the proposed Act. The definition makes no reference to social welfare or public interest. There is no explicit mention of organic changes leading to the conclusion that the definition of the term 'innovation' is in dire need of revision.

Currently, there is no correlation between the title of the Act and the object and purpose that it seeks to achieve. The title of the Act reads 'The National Innovation Act, 2008' and it names among its objectives the amendment and consolidation of laws relating to confidential information and the protection of trade secrets in India. Here the Act tries to address two dissimilar issues. While the title implies that the Act deals only with innovation and other allied issues, the body of the legislation combines this with different subject matters, namely confidential information and trade secrets. Therefore, while the title implies one issue, the provisions under the Act discuss another issue resulting in a mismatch of title, object and provisions. 53 The structure of the Act has the features of an intellectual property policy on innovation rather than a proposed legislation relating to innovation per se. There is a need to consolidate the differences between the Patents Act, 2005 and the Competition Act, 2002 by means of an Innovation Act and not merely supplementing the existing intellectual property law.

http:/ / www.mondaq.com/india/x/67750/Patent/A+Probe+On+The+Pr oposed+National+Innovation+Act +2008 .

53 DUTZ, supra note 50. 


\section{Conclusion and Suggestions}

1. The Indian legislations on innovation and competition must incorporate aspects of dynamic analysis into their provisions. Dynamic analysis views competition through a broader lens and focuses less on outcomes and more on the process. It favours maintaining rivalry but also protects property, including intellectual property. The working assumption in dynamic competition analysis is that intellectual property rights are desirable institutional or legal arrangements providing necessary appropriability mechanisms to advance and incentivize innovation. Dynamic analysis also recognizes that the benefits of dynamic competition do not arrive immediately; firms may need to tolerate some short term inefficiency to support innovation. ${ }^{54}$

2. For reasons of promoting dynamic competition, developing countries should require rapid publication of patent applications with full disclosure of the technical processes involved in producing the inventions and in reducing them to commercial practice. This would encourage local firms to invent patents and use the disclosed knowledge to improve their manufacturing methods. This will also serve to prevent an applicant's competitor from investing substantially in a product, only to learn, once the patent is finally issued, that it infringed a rival's patent and that he now owes them significant royalties. Countries with a registration system should permit active opposition after grants are made, in order to invalidate inappropriately awarded patents. Those countries that undertake examination could permit pre-grant opposition. 55

\footnotetext{
54 SIDAK \& TEECE, supra note 8.

55 Intellectual Property: Balancing Incentives with Competitive Access, GLOBAL

22,

2015), 
Ketana Krishna et al.

3. The definition of 'abuse of patents' ought to be 'the unjustifiable use of the IPRs causing damage to the interest of the consumers and the society at large. 56

4. The merger guidelines should be properly implemented to avoid concentration of intellectual property in IPR rich companies to ensure the equitable distribution of patents. ${ }^{57}$

5. Holding of a patent is important only for the assessment of market power in case the patented technology confers a significant competitive advantage on the patent holder. ${ }^{58}$ Many patents merely allow their owners to differentiate their products or enjoy a slight cost advantage, not enough to create genuine antitrust market power. ${ }^{59}$ Thus, the Innovation Act should strive to negate the presumption of market power created by patents.

6. The acquisition of intellectual property rights with the purpose of strengthening monopoly power in the market should be regulated properly, with clear technology transfer guidelines incorporated in the Act. ${ }^{60}$

7. An exercise of harmonisation by virtue of the Innovation Act is necessary to undo the overriding effect of Section 60 of the Competition Act over the Patents Act.

8. An administrative procedure should be created to evaluate cooperative arrangements among firms with higher market shares for their dynamic efficiency gains and anti-

56 RAJU, supra note 6.

57 Rosabeth Moss Kanter, The Experts: Does the Patent System Encourage Innovation?, THE WALL STREET JOURNAL, (May 16, 2013), http://online.wsj.com/news/articles/SB10001424127887323582904578487 200821421958.

58 Carl Shapiro, Antitrust, Innovation, and Intellectual Property, TESTIMONY BEFORE THE ANTITRUST MODERNIZATION COMMISSION (Nov. 8, 2005), http:/ / faculty.haas.berkeley.edu/shapiro/amcinnovation.pdf.

${ }^{59} \mathrm{Id}$.

60 RAJU, supra note 6. 
competitive nature. Processes should be such as to result in sufficient incentives for regulatory bodies to detect and prove cases of abusive cooperative arrangements. Procompetitive arrangements can be certified to pre-empt antitrust litigation in future. 61

The traditional view that IPR laws and competition laws are contradictory is a misconception. The National Innovation (Draft) Act seeks to harmonize the two legislations. However, there is scope for improvement to this piece of legislation and since it has not yet been implemented it remains to be seen whether this legislation will result in the promotion and growth of innovation.

${ }^{61}$ Rakesh Basant \& Sebastian Morris, Competition Policy in India Issues for a Globalising Economy, ECONOMIC AND POLITICAL WEEKLY, (Jul. 29, 2000), http://www.iimahd.ernet.in/ morris/development/CompPolicy.pdf. 